\title{
Reposisi Peran dan Fungsi Strategis Public Relations Dalam Organisasi
}

\author{
Oleh: \\ Lena Satlita \\ lensa@uny.ac.id
}

Abstrak

Public Relations (PR) adalah fungsi khas manajemen yang mondukung pembinaan dan membangun upaya saling monguntungkan melalui komunikasi, pengertian, penerimaan dan korjasama yang baik antara organisasi dengan publiknya. Walaupun porkembangan PR saat ini telah lebih baik dari sepuluh tahun yang lalu, tetapi tidak bisa dipungkiri bahwa beragamnya persepsi. tentang PR, tolah membawa PR (khususnya Indonesia) menuju arah yang koliru dan belum memperoleh apresiasi yang layak atau sejajar dongan profesi lain.

Tulisan ini akan menguraikan konsep dasar PR, rmembahas peran dan fungsi strategis public relations dalam organisasi dan bagaimana mereposisi peran dan fungsi strategis ini agar PR dapat mengaktualisasikan dirinya sebagai bagian dari koalisi dominan dalam organisasi.

Untuk mampu mewujudkan peran dan fungsi strategisnya, semua pihak yang terkait dengan PR perlu duduk bersama untuk mengubah paradigma, menyamakan persepsi mengenai substansi PR dan mengambil langkah-langkah untuk menghasilkan PR Profesional yang mampu memberi kontribusi terhadap organisasi khususnya dalam mengelola hubungan harmonis jangka panjang antara organisasi dengan publiknya agar reputasi organisasi tetap terjaga.

\section{Pendahuluan}

Public relations (PR) atau hubungan masyarakat (humas) telah menjadi "trend" manajemen di Indonesia, dengan berbagai istilahnya. Hal ini bisa dilihat dari dibentuknya "bagian" atau "divisi" PR dalam banyak perusahaan, profit maupun non profit. PR juga berkembang dengan analogi yang beragam, tergantung bagaimana orang mempersepsinya. Ada yang mendeskripsikan tugas PR sebagai protokoler, fotografi, tugas mengatur dan menservis wartawan, menjawab berita, mengkliping koran, mengelola buletin, event organizer sampai dengan analog sebagai "pe- 
nyelamat" organisasi dari citra buruk di mata masyarakat. PR sampai saat ini juga dipersepsi sebagai "dunianya" perempuan cantik, pria necis, glamour, menarik, wangi, memiliki relasi yang luas, sehingga untuk menjadi seorang PR dianggap mudah, tidak memerlukan kompetensi tertentu.

Berbagai persepsi tentang PR telah membuat dunia PR Indonesia tumbuh pada arah yang keliru dan melahirkan pandangan sinis terhadap profesi ini. Hal ini membuahkan penilaian dan apresiasi kepada PR Indonesia secara tidak proporsional. Dalam convenient sampling yang dilakukan terhadap peserta Konvensi Humas di Yogyakarta tahun 1998 (Elizabeth G.Ananto, 2004) terungkap bahwa responden menganggap bahwa profesi PR belum mendapat tempat yang layak atau sejajar dengan profesi lain. Hal ini disebabkan karena kurangnya apresiasi pimpinan lembaga (39\%), terjadi kesalahan persepsi mengenai profesi PR $(31 \%)$, keterbatasan kemampuan praktisi PR (22\%), tidak adanya persyaratan khusus untuk melaksanakan profesi PR (8\%). Hal senada terungkap kembali dalam dialog selama Konvensi Humas di Yogyakarta pada bulan Desember 2004 yang baru lalu.

Di sisi lain, banyak pihak yang sepakat dan mengakui bahwa PR memiliki peran dan fungsi yang penting dalam organisasi. PR Mana- ger PT Newmont mengakui, krisis "Kasus Buyat" yang menimpa perusahaannya, yang sempat menjadi pemberitaan berskala nasional (bahkan internasional)sehingga reputasi Newmont tercederai, dikarenakan tidak mengantisipasi sebelumnya, tidak mengoptimalkan peran dan fungsi PR, berakibat sangat mahal. Perusahaan Coca Cola mewajibkan karyawannya yang akan dipromosikan ke jenjang manajer senior, perlu mengikuti pelatihan atau kursus PR yang diadakan perusahaan tersebut. Waktu Perang Teluk 1990, Kuwait menyewa Hill\& Konwlton sebuah perusahaan PR di Amerika untuk memperoleh dukungan rakyat Amerika bahkan pemerintah Indonesia menyewa sebuah perusahaan PR " Sawyer Miller" dari Amerika dengan bayaran satu juta dolar waktu penyelenggaraan APEC di Bogor pada tahun 1994.

Apa yang salah dengan PR di Indonesia? Benarkah peran dan fungsi PR dalam organisasi penting? Mengapa PR yang cikal bakal prakteknya telah muncul disekitar proklamasi kemerdekaan Indonesia masih belum dimaknai seperti seharusnya? Tulisan ini mencoba menguraikan bagaimana memposisikan kembali peran dan fungsi strategis PR dalam organisasi agar mampu mengaktualisasikan dirinya pada tataran fungsi manajemen strategis, selaku ujung tombak dalam mem- 
buka peluang baru untuk peningkatan kinerja organisasi.

\section{Konsop Dasar Public Relations.}

Momahami PR melalui satu alau dua definisi tidaklah mudah, karona sebuah definisi yang ada m11ngkin tidak mampu menggambarkan substansi kegiatan PR sesungguhnya. Persoalannya, definisi yang mana yang akan dipilih, mengingat begitu banyak definisi PR yang telah dikemukakan oleh berbagai kalangan: praktisi, para penulis buku loks, maupun sejumlah organisasi praktisi PR diberbagai belahan dunia. Banyaknya definisi PR mungkin juga merefleksikan kenyataan praktik sohari-hari PR dalam berbagai lingkungan sosial atau mungkin merefloksikan evolusi yang sedang terjadi dalan fungsi PR pada organisasi.

Grunig dan Hunt mendefinisikan kegiatan PR sebagai kegiatan komunikasi, "the management of communication between an organization and its public (Baskin, Aronoff dan Lattimore, 1997:5). Senada dengan Grunig, Jefkins melihat PR terdiri dari seluruh kegiatan komunikasi yang terencana dengan semua publiknya dalam rangka mencapai tujuan spesifik (1999:9). Sedangkan Harlow berpendapat PR merupakan komunikasi dua arah antara organisasi dengan publik secara timbal balik dalam rangka mendukung fungsi dari tujuan manajemen dengan meningkatkan pembinaan kerjasama serta pemenuhan kepentingan bersama (Ruslan, 1999:102).

Definisi- definisi di atas menjelaskan bahwa PR merupakan kegiatan komunikasi yang dilakukan sebuah organisasi dengan berbagai publiknya. Domain kegiatan PR adalah komunikasi dalam bentuk komunikasi dua arah. Di satu sisi, organisasi melakukan penyebaran informási kepada publik. Di sisi lain organisasi juga melakukan pencarian informasi, mendengarkan apa yang menjadi keinginan publik organisasi.

Definisi lain mengkonsepsikan PR lebih dari sekedar kegiatan komunikasi. PR adalah sebuah fungsi manajemen yang berkaitan dengan usaha untuk membangun hubungan yang saling menguntungkan (mutualIly beneficial relationship) antara sebuah organisasi dengan publiknya, seperti yang dinyatakan oleh Cutlip, Center dan Broom (1994:6), " the management function that establishhes and maintains mutually beneficial relationship between an organization and the publics on whom its success or failure depend". Cutlip dkk melihat PR sebagai fungsi manajemen untuk membangun dan menjaga hubungan yang saling menguntungkan antara organisasi dan publiknya yang menentukan keberhasilan atau kegagalan organisasi tersebut. Pertemuan asosiasi PR seluruh dunia di Mexico City (1978) mendefinisikan PR sebagai: "suatu seni sekaligus suatu disiplin ilmu so- 
sial yang menganalisis berbagai kecenderungan, memperkirakan setiap kemungkinan konsekuensi darinya, memberi masukan dan saran-saran kepada pemimpin organisasi, serta menerapkan program-program tindakan yang terencana untuk melayani kebutuhan organisasi dan atau kepentingan khalayaknya". Sementara IPR (Institute of Public Relations) menjelaskan PR sebagai “ keseluruhan upaya yang dilangsungkan secara terencana dan berkesinambungan dalam rangka menciptakan dan memelihara niat baik dan saling pengertian antara suatu organisasi dengan segenap khalayaknya".

Ngurah (1999) menyimpulkan bahwa pengertian PR sesungguhnya adalah relations with public. Ketika organisasi berbicara relations with public, maka harus dipahami pula bahwa masing-masing pihak yang sedang membangun hubungan memiliki kepentingan. Organisasi memiliki kepentingan, begitu juga dengan publik. Hubungan yang ada di dalamnya harus terlaksana dengan baik, demikian juga dengan dunia luar karena organisasi mengandung arti: ia harus utuh, bersatu dan harmonis dalam mencapai tujuan.Hubungan kedua belah pihak akan berjalan harmonis bila masingmasing dapat saling mempertimbangkan kepentingan pihak lain.

Lebih lanjut Ngurah mengatakan jika kedua konsep PR ini disin- tesakan, maka dapat dikatakan bahwa kegiatan komunikasi yang dilakukan bagian PR tidak hanya berhenti ketika pesan atau informasi sudah tersebar, tetapi komunikasi yang terjadi antara organisasi dan publiknya harus mampu melahirkan perubahan baik pada publik maupun pada organisasi. Organisasi akan melakukan penyesuaian terhadap tuntutan publik, sehingga akan terjadi hubungan yang harmonis, saling mendukung antara kedua belah pihak. Karena organisasi diasumsikan beroperasi lantaran diberi hak oleh publik dan bahwa hak itu tidak bisa dihindari, manajemen setiap organisasi memiliki kewajiban memberikan layanan kepada publik dengan sebaik-baiknya. Pada titik inilah, urgensi PR ditemukan. PR lahir untuk sebuah fungsi strategik: menjadi reperesentasi organisasi dalam membangun dan memelihara hubungan dengan publik. PR adalah manajemen hubungan antara sebuah organisasi dengan seluruh publik (stakeholder)nya, dengan peranan komunikasi kunci yang membentuk dan melindungi reputasi organisasi.

\section{Peran dan Fungsi Public Relations Dalam Organisasi. \\ PR sebagai alat manajemen} modern, maka secara struktural merupakan bagian integral dari suatu kelembagaan atau organisasi, artinya PR bukanlah merupakan fungsi terpisah dari fungsi kelembagaan 
alau organisasi tersebut. Sejalan denuan konsop PR yang berkembang hiill adalah konsep yang menekankan pontingnya komunikasi dua arall, monurut Howard Childs (Ngu|alı, 19995), fungsi dasar PR bukan iriluk monampilkan pandangan orunnitasi atau seni sikap publik, te(âj) untuk melakukan rekonsiliasi alau ponyesuaian terhadap kepenlingan publik setiap aspek pribadi oruiwisasi maupun perilaku perusahaan yang punya signifikansi sosial. Jadi di sini PR berfungsi membantu organisasi melakukan penyesuaian lorhadap lingkungan tempat organisasi torsobut beroperasi.

Konsep tersebut punya konsokuonsi penting, karena penyesuaian organisasi mengisyaratkan sebuah fungsi yang berada pada level manajomen organisasi. Konsep ini monokankan pentingnya tindakanlindakan perbaikan yang harus dilakukan organisasi di samping usahausaha untuk berkomunikasi. PR sebagai fungsi manajemen berkaitan dongan bagaimana sebuah organisasi menyusun kebijakan sehingga momperlihatkan sebuah kinerja yang bortanggungjawab. Ini berkaitan dengan kenyataan bahwa penampilan yang bertanggungjawab merupakan dasar penerimaan publik terhadap sebuah organisasi. Hal ini berarti, PR sebuah organisasi tidak sematamata menjadi tanggungjawab praklisi PR tetapi harus menjadi tanggungjawab para pengelola organisasi tersebut. Praktisi PR dalam konteks PR sebagai fungsi manajemen harus membantu organisasi dalam membangun filosofi-filosofinya, mencapai tujuan-tujuan yang ditetapkan, beradaptasi dengan lingkungannya dan bisa sukses dalam berkompetisi merebut sumber-sumber bagi kelangsungan hidup organisasi. Seperti yang dikatakan Baskin dan Aronoff (Ngurah, 1999:9), "All managers, indeed, virtually all employees, represent their organization to some public".

PR sebagai fungsi komunikasi, perlu dipahami bahwa kegiatan utama PR adalah melakukan komunikasi. PR sebagai fungsi staff khusus yang melayani para pemimpin organisasi, khususnya dalam membantu organisasi berkomunikasi dengan publik-publiknya. Onong (1998:36) mengemukakan bahwa fungsi PR meliputi hal-hal sebagai berikut:

1.Menunjang kegiatan manajemen dalam mencapai tujuan organisasi.

2. Menciptakan komunikasi dua arah secara timbal balik dengan menyebarkan informasi dari perusahaan kepada publik dan menyalurkan opini publik pada perusahaan.

3. Melayani publik dan memberikan nasihat kepada pimpinan organisasi untuk kepentingan umum. 
4. Membina hubungan secara harmonis antara organisasi dengan publik, baik internal maupun eksternal.

Fungsi PR menyelenggarakan komunikasi dua arah secara lebih terinci dijelaskan oleh Bachtiar Aly (1999) sebagai berikut:

1. Memberikan penerangan yang berkaitan dengan kepentingan organisasi dan kepentingan khalayak dengan cara-cara yang sesuai dengan jamannya.

2. Mengukur dan menafsirkan sikap, pendapat dan perilaku masyarakat terhadap organisasi, sehingga tercapainya misi pesan yang dikehendaki

3. Merumuskan kegiatan-kegiatan yang bertujuan meningkatkan pengertian masyarakat terhadap aktivitas lembaga/perusahaan

guna memperoleh dukungan publik.

4. Melaksanakan dan mengembangkan setiap program yang berhubungan dengan usaha untuk menciptakan saling pengertian antara organisasi dan masyarakat, sehingga terjalin kerjasama yang diharapkan.

5. Melakukan evaluasi internal sejauhmana terjalinnya kerjasama harmonis dan sam- pai dimana telah terciptanya persepsi positif masyarakat dan citra organisasi yang didambakan.

Jadi jelaslah bahwa PR bukan sekedar fungsi teknis tetapi merupakan fungsi manajerial yang bertanggungjawab atas terselenggaranya suatu hubungan yang signifikan antara organisasi dengan publik (stakeholder) nya. PR adalah sebuah fungsi strategik di tingkat korporasi. PR adalah jembatan, pembangun dan pemelihara harmoni antara organisasi dan lingkungannya. Dengan harmoni, saling pengertian yang lebih baik antara organisasi dengan publiknya, citra positif organisasi diharapkan terbentuk dan menguat. PR memiliki visi membangun dan memelihara citra organisasi sebagai korporasi yang berhasil, baik secara ekonomi maupun sosial. Karena korporasi yang berhasil, akan diterima masyarakat sebagai bagian dari aset mereka, aset suatu bangsa/negara.

Dalam kaitan menjalankan fungsi membina saling pengertian dengan publiknya menurut Indrawadi Tamin (2004) ada empat peran yang dapat dimainkan oleh PR , yaitu:

1. Interpreter atau in the middle, yaitu PR berperan sebagai sumbu antara manajemen dengan publik internal maupun eksternal. PR harus 
mampu menginterpretasikan dinamika dan kebutuhan sorta perilaku publik terhadap manajemen dan sebaliknya. Untuk bisa memikul poran ini, PR harus punya akses pada manajemen bahkan top manajemen.

2. Lubricant, pelumas atau pelicin untuk terciptanya hubungan internal yang harmonis dan efisien. Peran ini memungkinkan PR mencegah timbulnya kemungkinan friksi-friksi atau perpecahan dalam organisasi.

3. Monitoring dan Evaluasi. Peran ini untuk mengantisipasi setiap perubahan yang mungkin saja berdampak negatif terhadap organisasi.

4. Komunikasi. komunikasi dilakukan baik pada publik eksternal maupun internal untuk terciptanya saling pengertian.

Berbagai penelitian yang lilakukan di Amerika Serikat mengdontifikasikan dua peran yang meionjol yang dijalankan seorang prakisi PR dalam sebuah organisasi yalu peran manajer dan peran teknisi. tal mendasar yang membedakan codua peranan ini adalah pada keorlibatan praktisi PR dalam proses sengambilan keputusan ditingkat кorporat. Manager terlibat dalam proses pengambil keputusan sedangkan para teknisi tidak berpartisipasi dalam pengambilan keputusan manajemen. Secara ideal, kedua peranan harus ada dalam praktek PR pada sebuah organisasi karena pada dasarnya, peran-peran tersebut saling melengkapi. Manajer melakukan perencanaan, memimpin, memilih staf, mengatur jadwal, menyusun anggaran kegiatan PR, sedangkan para teknisi melaksanakan seluruh kegiatan PR, sehingga program PR dapat berjalan dengan baik, terarah dan tepat sasaran.

Peranan praktisi PR dalam organisasi merupakan salah satu kunci penting untuk pemahaman fungsi PR dan komunikasi organisasi. Hanya dengan menjalankan peran manajer realisasi $P R$ yang profesional dapat tercapai, karena ada dua hal penting ketika praktisi PR (PRO) menjalankan peranan manajerial; (1), mereka merupakan bagian dari koalisi dominan dalam organisasi dan terlibat dalam proses pengambilan keputusan yang memutuskan perencanaan strategik,dan (2), mereka mengelola bagian PR tanpa campur tangan bagian lain dan bertanggungjawab secara penuh terhadap programnya. Dalam peran sebagai manajer, praktisi PR lebih mudah untuk menjalankan fungsi utamanya yaitu membina hubungan harmonis antara organisasi dengan publiknya, mengintegrasikan sikap dan perbuatan suatu lembaga dengan sikap dan per- 
buatan publik atau sebaliknya. Berbagai buku teks dalam bahasa Inggaris maupun bahasa Indonesia, seialu menempatkan PR yang ideal baik secara fungsi maupun struktur. Permasalahannya, mengapa praktisi PR menjalankan peranan yang berbeda-beda dalam berbagai organisasi? Elizabeth Goenawan Ananto dalam makalahnya yang dipresentasikan di depan peserta Konvensi Humas di Yogyakarta (2004), mengungkapkan beberapa kajian tentang peran dan fungsi PR, antara lain kajian yang dilakukan Dolphin dan Fan menyimpulkan bahwa kebanyakan organisasai di Inggeris menempatkan komunikasi korporat pada jenjang ke 3 dalam organisasi. Kajian di Australia yang dilakukan Steinner dan Black menyimpulkan bahwa hanya sedikit organisasi di Australia yang mempraktekkan "symmetrical public relations" yang dapat terjadi jika praktisi PR berada pada posisi perencanaan korporat. Bagaimana di Indonesia? Belum banyak hasil penelitian mengenai posisi PR dalam organisasi. Kurangnya kajian ilmiah mengenai peranan PR sebagai fungsi manajemen, serta kurangnya informasi publik terhadap perkembangan profesi ini, merupakan salah satu faktor rendahnya apresiasi publik terhadap profesi ini. Kajian pada tahun 2001 (Ananto, 2004:6), menunjukkan bahwa posisi PR dalam organisasi paling banyak berada pada posisi staff $(52 \%)$, manager (39 \%) dan direktur (9\%), sedangkan kajian tahun 2004 terdapat peningkatan posisi PR yaitu pada level Vice President (5\%). Kalau mau disebut dari sedikitnya organisasi/ perusahaan yang menempatkan PR dalam posisi yang ideal, antara lain PT Astra Internasional yang menempatkan posisi PR nya pada tingkatan pimpinan tertinggi dengan jabatan Senior Vice President Director, begitu juga dengan PT Telkom Tbk, yang memposisikan PR dalam kedudukan Vice President Corporate Communication (wakil direktur utama bidang komunikasi perusahaan).

Pada mulanya sejumlah riset memperkirakan faktor lingkungan organisasi mempengaruhi praktek PR dalam sebuah organisasi. Namun karena ketiadaan bukti-bukti yang kuat, maka Grunig (Ngurah, 1999) lebih melihat keputusan para pemegang kekuasaan dalam organisasi yang menentukan, budaya organisasi, potensi yang dimiliki oleh bagian PR dan pemahaman para pemegang kekuasaan terhadap PR. Sebuah organisasi yang menganut budaya otoriter cenderung akan mempraktekkan sistem manajemen tertutup sehingga mempraktekkan model asimetris. Bagian PR yang tingkat profesionalnya rendah, hanya handal dalam menjalankan pekerjaan teknis, tidak punya kemampuan riset, juga penting sebagai faktor yang mempengaruhi praktek PR 
Jalam organisasi. Dari berbagai kajian yang dilaporkan oleh Ananto, juga lorungkap temuan antara lain: oksokutif dan manager dari bagian lain kolihatan frustrasi dengan kiI 1 ija I'R dalam perusahaan mereka, oksokulif dan manajer berpendapat baliwa potugas PR tidak mempunyai pengetahuan yang cukup tentang bisnits porusahaan, manajer dari (livisi lain tidak mendapat informasi yang cukup mengenai peran dan lungsi PR, selain daripada media rolations yang banyak dilakukan oleh Iraklisi PR, rendahnya kemampuan I'l' melakukan negosiasi, mengatasi konflik, telah mengurangi rasa percaya Pimpinan Puncak Organisasi/l'orusahaan (CEO) terhadap kemampuan PR. Terdapat perbedaan yang signifikan antara harapan CEO dan apa yang dilakukan PR mereka (2004 4-5).

\section{Roposisi Peran dan Fungsi} Stratogis Public Relatuions

Program dan aktivitas PR akan lobih optimal dan mencapai sasaran yang telah ditentukan, sehingga tercapainya pembentukan citra positif dan reputasi yang baik, tentunya harus ditunjang oleh fungsi dan struktur PR dalam organisasi. Menurut Grunig (1992), praktisi PR biasanya lidak mempunyai kebebasan untuk bortindak sebagai seorang profesional, kecuali jika ia dudık dalam jajaran top manajemen (pimpinan tertinggi) yang disebutnya sebagai koalisi dominan yaitu pihak-pihak dalam organisasi yang memiliki kewenangan lebih dalam memberi arah perkembangan organisasi termasuk menentukan visi, misi, perangkat serta struktur kelengkapan organisasi. Koalisi ini merupakan penentu dalam pengambilan keputusan dan yang mengendalikan berputarnya roda organisasi.

Jika unit PR menjadi bagian koalisi yang dominan yang menentukan arah organisasi, maka tujuan PR akan menjadi tujuan organisasi. PR mempunyai wewenang untuk memasukkan unsur tanggungjawab sosial, pemahaman publik dan komunikasi dua arah dalam seluruh kegiatan organisasi. Dengan demikian PR akan memiliki peluang yang cukup besar dalam membentuk suatu hubungan jangka panjang dengan stakeholdemya. Hanya dengan cara ini akan lebih mudah dapat dilihat kontribusi PR terhadap efektifitas organisasi. Sebaliknya jika eksekutif PR tidak duduk dalam koalisi yang dominan, akan sulit menentukan fungsi PR, betapapun pelaksana PR berusaha untuk memenuhi tujuan komunikasinya.

Kajian Excellen dari IABC (Ananto, 2004) menekankan ada 3 faktor kunci untuk memberdayakan fungsi public relations secara efektif yaitu: 1) Nilai yang diberikan oleh CEO serta koalisi yang dominan dalam organisasi, 2) Peran dan perilaku dari pejabat komunikasi dan 
3) Budaya organisasi. Sementara ciri fungsi PR yang efektif dapat dijabarkan dalam 4 dimensi, yaitu: pemberdayaan fungsi, peranan komunikator, pengaturan fungsi komunikasi dan model PR. Nilai yang diberikan kepada fungsi PR dalam organisasi akan memberikan arahan secara prinsip bagaimana fungsi public relations akan diatur.

Melihat kenyataan yang ada bahwa peran dan fungsi PR belum ditempatkan dalam posisi strategis seperti terungkap dalam berbagai penelitian yang telah diurai diatas, perlu kiranya ada upaya-upaya untuk mereposisi peran dan fungsi strategis PR dalam organisasi. Upaya ini lebih dimaksud kepada upaya untuk mengubah paradigma,menyamakan persepsi mengenai substansi PR pada semua praktisi PR, lembaga pendidikan PR, organisasi profesi PR . PR hendaknya berkembang tidak hanya sekedar asesoris dalam menjalankan fungsi dan struktur-struktur organisasi/ perusahaan, tetapi menjadi fungsi manajemen untuk mencapai tujuan organisasi, terutama bergerak dalam membentuk citra positif dan memelihara reputasi baik sebuah organisasi.

Ananto (2004) menegaskan bahwa PR harus masuk dalam koalisi dominan agar dapat menjalankan peran dan fungsi strategisnya. Untuk mendapatkan pengakuan sebagai anggota dari koalisi yang dominan atau masuk dalam jajaran pimpinan tertinggi, praktisi PR bukan hanya dituntut mengetahui bagaimana caranya berkomunikasi dengan segala teknis dan strategi, tetapi lebih dari itu kemampuan manajerial, strategik, holistik dan etik. PR harus memiliki pengetahuan yang mendalam mengenai visi organisasi, kemampuan menganalisis trend yang berkembang, kemampuan berfikir dan bertindak secara manajerial, kemampuan untuk memberikan solusi terhadap masalah yang timbul, wawasan luas, analisis tajam serta kemampuan untuk menyajikan data yang diperlukan untuk keputusan manajemen melalui riset. Kemampuan dan keahlian para praktisi PR idealnya haruslah mampu "mempengaruhi" manajemen puncak (CEO) dan nilai-nilai inidividu (values) para praktisi PR akan sangat menentukan keberhasilannya dalam menjalankan peran profesionalnya.

Pertanyaannya, - mampukah PR (khususnya di Indonesia) masuk dalam jajaran manajemen puncak/pimpinan tertinggi ? Mampukah pendidikan PR di Indonesia menghasilkan lulusan yang dapat diharapkan sebagai koalisi yang dominan? Bagaimana peranan organisasi profesi PR dapat membantu praktisi PR sebagai koalisi yang dominan? Semua pihak yang terkait dengan PR , harus mau duduk bersama untuk memikirkan masa depan profesi ini.

Pendidikan PR di semua tingkatan perlu berjuang keras untuk 
II0nuhlasilkan PR yang profesional. I ombaga pondidikan PR harus |wkㅂ.jasuma dengan para pengguna miluk mongetahui tentang kualitas liaklisi l'le yang diperlukan pasar, III011ualnk praktisi untuk mengajar, $1110 m b e r i k a n$ pengalaman bagi dosen I'll dongan cara memberikan hвьยmpatan kerja beberapa bulan di forlusillaan, mendisain program IIrayang agar mahasiswa mendapat pengalaman kerja yang optimal, dan sobagainya. Lembaga pendidikan kolımasan perlu menunjukkan komilmon dan langkah-langkah nyata ponirykatan kualitas dengan mengambil prakarsa dan terobosanleroloosan baru (Noeradi, 2004).

Organisasi profesi PR, harus lobilı momainkan perannya sebagai sllalu organisasi yang mampu memberdayakan dan membina anggotaIIya, momberikan peningkatan kemampuan dengan cara secara berkala mongadakan training, seminar, lokakarya dan sejenisnya. Organisasi profesi juga dapat berperan sobagai suatu organisasi yang "mengontrol" dan "menilai" dengan menontukan standar kompetensi dan mongeluarkan sertifikasi bagi orangorang yang akan terjun dalam profosi ini.

Praktisi PR dituntut untuk meningkatkan kemampuan dirinya, melakukan pendekatan PR secara lebih strategis melalui research-based knowledge atau melakukan riset untuk menciptakan pengetahuan yang diperlukan (Ananto, 2004). Hanya dengan peningkatan kualitas diri, pratisi PR dapat mempersenjatai diri dengan data untuk dapat berargumen dengan anggota koalisi dominan yang lain. Dan hanya dengan kemampuan untuk menyajikan data, praktisi PR dapat duduk dalam decision making table. Tanpa itu, praktisi PR hanya akan dianggap sebagai pemanis organisasi, yang akan dicari karena diperlukan, dan dilupakan jika semuanya sudah berjalan lancar.

\section{Penutup}

Fungsi utama PR adalah membantu organisasi agar ia selalu punya hubungan harmonis dengan berbagai publiknya melalui kegiatan komunikasi. Konsep PR sebagai komunikasi dua arah menekankan pentingnnya pertukaran komunikasi atau saling memahami dengan penekanan pada penyesuaian organisasi. Karena dengan hubungan yang demikian itulah, publik sebuah organisasi akan mendukung keberadaan organisasi, program-program dan kebijakan organisasi.

Fungsi PR akan lebih optimal dan mencapai sasaran yang telah ditentukan apabila ditunjang oleh fungsi dan struktur dalam organisasi yaitu duduk sebagai bagian dalam top manajemen (koalisi dominan). Karena dalam prakteknya, PR belum mendapat apresiasi yang semestinya, perlu upaya-upaya untuk 
mereposisi peran dan fungsi strategis PR dalam organisasi. Semua pihak yang terkait dengan PR (praktisi PR, lembaga pendidikan $P R$, organisasi profesi PR) perlu duduk bersama untuk menyamakan persepsi dan langkah-langkah peningkatkan kemampuan SDM PR. Praktisi PR perlu meningkatkan kemampuannya selain komunikasi juga kemampuan manajerial, strategik, etik, riset, dan sebagainya agar dapat mempengaruhi manajemen puncak dan menjalankan peran profesionalnya.

Sebagai catatan akhir, mau dibawa kemana profesi ini, bagaimana masa depan profesi ini, pada akhirnya kembali pada setiap orang yang terkait dengan profesi PR, sejauhmana PR mau memposisikan diri dalam organisasi. Puas dengan kondisi yang ada sekarang atau berjuang untuk memperoleh apresiasi yang layak dan sejajar dengan profesi lain.

\section{Daftar Pustaka.}

Basikin, O., \& Aronof, C. 1997. Public Relations:The Profession and the Practice. Edisi Keempat, Madison,Wl: Brown \& Benchmark.

Cutlip, S.M.,Center,A.H. \& Broom, G.M. 1994. Effective Public Relations. Edisi keenam. New Jersey: Prentice Hall.
Elizabeth Goenawan Ananto. 2004. "Public Relations, Sebagai Koalisi Yang Dominan, Mungkinkah?", makalah pada Konvensi Perhumas di Yogyakarta.

Grunig, J.E. 1992. Excellence in Public Relations and Communication Management. New Jersey, Lawrence Erlbaum Associte, Inc.

I Gusti Ngurah Putra. 1999. Manajemen Hubungan Masyarakat. Yogyakarta: Pener-bit UAJ. Jefkins, Frank. 1996. Public Relations (terjemahan). Jakarta: Penerbit Erlangga.

Onong Uchjana Effendy. 1998. Hubungan Masyarakat. Bandung: PT Remaja Rosdakarya.

Rosady Ruslan.1999. Manajemen Humas dan Manajemen Komunikasi. Jakarta: PT Raja Grafindo Persada.

Wisaksono Noeradi. 1994." Menuju Pendidikan Yang Market Oriented", makalah pada Konvensi Perhumas di Yogyakarta.

\section{Biodata Penulis}

Lena Satlita, adalah salah seorang staf pengajar di Program Studi Pendidikan Administrasi Perkantoran FIS - UNY 